\title{
Estimating hatchling sex ratios of loggerhead turtles in Cyprus from incubation durations
}

\author{
B. J. Godley ${ }^{1}$, A. C. Broderick ${ }^{1}$, N. Mrosovsky ${ }^{2, *}$ \\ ${ }^{1}$ Marine Turtle Research Group, School of Biological Sciences, University of Wales Swansea, Swansea SA2 8PP, \\ United Kingdom \\ ${ }^{2}$ Departments of Zoology, Physiology and Psychology, University of Toronto, Toronto M5S 3G5, Canada
}

\begin{abstract}
Incubation durations for loggerhead turtles Caretta caretta nesting at Alagadi, in Northern Cyprus, were recorded over 6 full seasons (1993 to 1998). Because incubation duration depends on temperature, it was possible to convert data on durations to hatchling sex ratios, using extensive data from other areas on the relationship between these 2 variables. It was estimated that 89 to $99 \%$ of the hatchlings produced on Alagadi beach were females. These findings provide a further instance of highly female-skewed sex ratios in loggerhead turtles.
\end{abstract}

KEY WORDS: Caretta caretta $\cdot$ Mediterranean - Sea turtle $\cdot$ Temperature $\cdot$ Sex ratios $\cdot$ Sex determination

Resale or republication not permitted without written consent of the publisher

\section{INTRODUCTION}

In many reptiles, the direction of sexual differentiation depends on the temperature prevailing during incubation. In marine turtles, warm temperatures during the middle third of incubation produce females, and cool temperatures produce males. Having phenotypic sex determined by temperature potentially allows for great flexibility in sex ratios. These could be skewed through the females choosing to nest at times or in places with particular temperatures. Temperature-dependent sex determination has been the subject of a number of studies (review in Mrosovsky 1994). The data from loggerhead turtles Caretta caretta appear particularly interesting.

Although it has been postulated that a 1:1 sex ratio might be the norm in species in which the costs of producing a male or female are the same (Fisher 1930), sex ratios skewed as much as $90 \%$ toward female have been found or inferred for loggerhead turtles hatching in the USA and in Brazil (Mrosovsky \& Provancha 1992, Marcovaldi et al. 1997, Hanson et al. 1998, Pro-

\footnotetext{
*Corresponding author. E-mail: mro@zoo.utoronto.ca
}

vancha \& Corsello 1998). These huge skews are theoretically challenging. However, it is conceivable that sampling biases were responsible, even though the sex ratio estimates were based on $\geq 5$ yr data. Another possibility is that the females hatching on the beaches in the USA and Brazil are balanced by males originating elsewhere. Analysis of mitochondrial (mt) DNA suggests that loggerhead turtles nesting in different parts of the world are genetically distinct (Encalada et al. 1998, Laurent et al. 1998), but information on nuclear DNA is needed to determine if males produced on one beach mate with females produced at a distant site.

Given these possibilities, it is of interest to determine the sex ratio of hatchling loggerhead turtles in populations nesting in other geographic areas. If more instances of extremely biased sex ratios are found, it makes it less likely that sampling error is responsible for the skewed ratios described to date. Moreover, if more areas are shown to be female-producing, it becomes less likely that a balanced overall sex ratio can be reached through male-biased production at other sites.

Sex ratios of loggerhead turtles in the Mediterranean have been little studied. Kaska et al. (1998) found a mean sex ratio of $81.6 \%$ female in a small sample 
( $\mathrm{n}=8$ ) of loggerhead clutches laid at 4 sites in Cyprus and Turkey over the 1995 and 1996 nesting seasons (10 June to 2 August). However it is not possible to tell if this sample was representative of the normal thermal conditions in these areas. In a preliminary report, Broderick \& Godley (2000) have drawn attention to the very short incubation durations for loggerhead turtles in Cyprus, implying warm, feminising conditions.

In this paper we estimate the sex ratios of loggerhead turtles hatching on a beach in Northern Cyprus from data on incubation durations collected there over 6 seasons. Two different methods of estimation were used.

The first method is based on a data set accumulated over several years for loggerhead turtles nesting in the USA. For these samples, sex was determined directly by histology of the gonads, and sex ratio plotted against incubation duration. The curve relating these 2 variables, based on samples from 76 clutches, has recently been summarised by Godfrey \& Mrosovsky (1997). We updated this curve by the addition of data from 13 more clutches (Fig. 1).

The second method has been devised for situations in which only a pivotal incubation duration (that duration giving $50 \%$ of each sex) is available from laboratory studies, and no field samples have been collected and sexed. In this method, there are 4 steps: (1) Incubation of eggs in the laboratory at various constant temperatures, followed by calculation of a pivotal incubation duration and a curve relating duration to sex ratio. (2) Adjusting this laboratory curve to one appro-

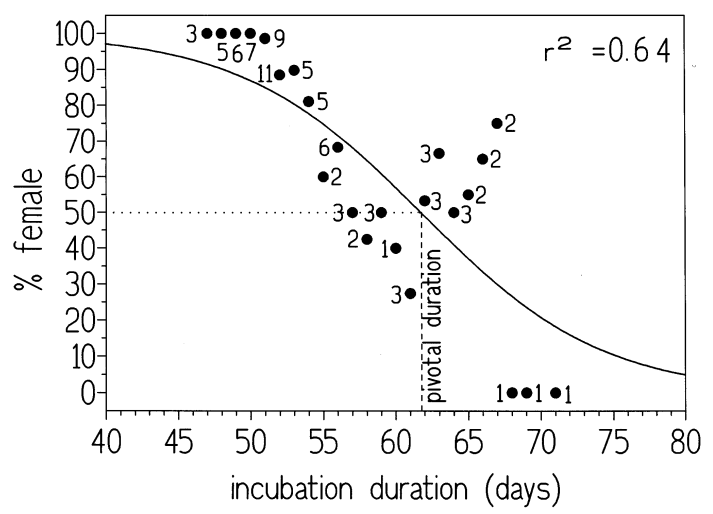

Fig. 1. Caretta caretta. Curve relating sex ratio and incubation duration of 89 clutches of loggerhead turtles nesting in south-eastern USA. Numbers beside points: number of clutches with that incubation duration. Sex ratio was usually based on samples of 10 hatchlings taken from a given clutch. Sources of data and further details are given in Godfrey \& Mrosovsky (1997). Present curve differs from that in Godfrey \& Mrosovsky in that it includes samples from 13 additional clutches from South Carolina. Horizontal dotted line: 50\% level; vertical dashed line: field pivotal incubation duration which by definition is the duration producing $50 \%$ of each sex

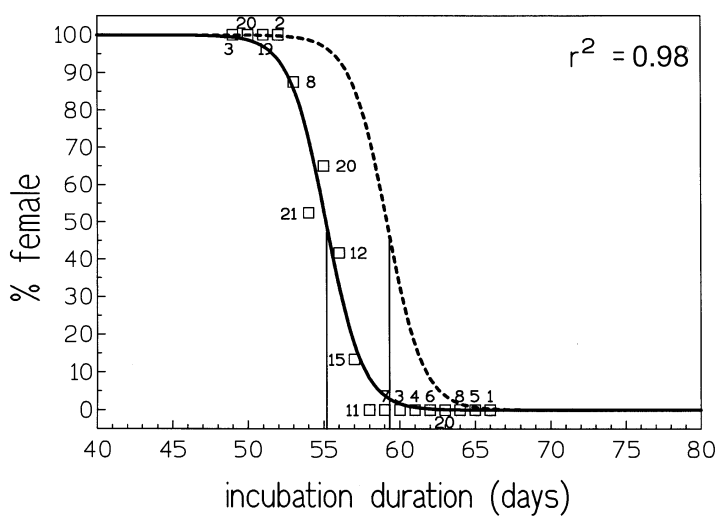

Fig. 2. Caretta caretta. Continuous line: relationship between sex ratio and incubation duration (laying to hatch) for Brazilian loggerhead turtle eggs studied in the laboratory (data from Marcovaldi et al. 1997). Numbers beside points: numbers of eggs at that duration (some of these $n$ values correct transcription errors in Marcovaldi et al. 1997, but make no difference to the shape of the curve); dashed line: derived curve obtained by adding hatch-emergence interval of $4.1 \mathrm{~d}$ (see Godfrey \& Mrosovsky 1997) to the incubation durations obtained in the laboratory (this derived curve was used to predict sex ratios from incubation duration [laying to emergence] available in the field); vertical lines: pivotal incubation durations

priate to the field by adding the hatch-emergence interval to the durations (Fig. 2). (3) Using the adjusted curve for converting values obtained in the field on incubation durations (duration from laying to hatchling emergence) to the corresponding values for sex ratios; this is done separately for different time bins within the season. (4) Calculating the overall sex ratio by taking into account the number of clutches deposited at different times within the nesting season. Examples of the use of this method and its validation are given in Marcovaldi et al. (1997), Godfrey et al. (1999) and Mrosovsky et al. (1999).

In the present case, no suitable data from laboratory work are available for Mediterranean loggerhead turtles. However, the physiology of sex determination appears to be a conservative characteristic in sea turtles (Mrosovsky 1994). The pivotal temperatures (those giving $50 \%$ of each sex) in studies of loggerhead turtles reported so far all cluster within a degree of $29^{\circ} \mathrm{C}$ (Mrosovsky 1994, Marcovaldi et al. 1997). Some limited data suggest that this is true of loggerhead turtles nesting in the Mediterranean. Although the sample of Kaska et al. (1998) from the eastern Mediterranean was too small to specify sex ratio in nature, it does provide an indication of pivotal temperature because temperatures in the nests were measured. Using the means of temperatures taken in the middle third of incubation (the thermosensitive period for sexual dif- 
ferentiation), the pivotal temperature was just below $29^{\circ} \mathrm{C}$. This is similar to the values of $29.2^{\circ} \mathrm{C}$ for Brazil (Marcovaldi et al. 1997), and $29^{\circ} \mathrm{C}$ for the USA (Mrosovsky 1994). Also, the pivotal incubation duration calculated by fitting a line to the data of Kaska et al. (1998) is $59.9 \mathrm{~d}$, which is close to the values of 59.3 and $61.7 \mathrm{~d}$ for Brazil and the USA, respectively. Although Kaska et al. did not take random samples of hatchlings from nests, their data indicate that the physiology of loggerhead turtles in the Mediterranean is quite similar to that of loggerhead turtles in the Americas with respect to thermal influences on sexual differentiation. The more extensive data sets from the latter areas can therefore be used to provide an estimate of the sex ratio of hatchling loggerhead turtles produced in Cyprus.

\section{MATERIALS AND METHODS}

Study site. The work took place at Alagadi $\left(35^{\circ} 33^{\prime} \mathrm{N}\right.$, $33^{\circ} 47^{\prime} \mathrm{E}$ ) in Northern Cyprus in the eastern Mediterranean. This is one of the main nesting areas in Cyprus for Caretta caretta (range in seasonal total of nests $=38$ to 95 per season from 1993 to 1998). The beach consists of 2 short coves, 0.8 and $1.2 \mathrm{~km}$ long, separated by a rocky headland. Extensive dunes and low scrub lie behind the beach itself. There is no shade on the beach. The climate is typical of the eastern Mediterranean, with virtually no rain from May to October and mean daily air temperatures during this period in the region of 20 to $30^{\circ} \mathrm{C}$. For further description of the study site, see Broderick \& Godley (1996) and Broderick (1997).

Data collection. From 1993 to 1998, nesting was recorded during nightly patrols, and emergences of hatchlings during early morning patrols. Data were collected from May to October each year, encompassing all nesting and hatching on this beach. Emergence was taken as the first day on which $>20$ hatchling tracks were seen at a nest. At Alagadi, $54 \%$ of nests had emergences confined to 1 night; of all hatchlings produced, more than $80 \%$ had emerged by the end of the first night (Glen et al. 2000). For analysis, data were grouped into half-month time bins by laying date.

\section{RESULTS}

\section{Incubation periods}

Incubation periods for Caretta caretta at Alagadi were short in all years (Table 1) with an overall mean incubation period of $48.0 \mathrm{~d}(\mathrm{SE}=0.7$, range $=42$ to $58, \mathrm{n}=227$ ).

\section{Sex ratios calculated using Method 1, based on USA field data}

Mean incubation durations for the main nesting season, June and July, were $\leq 50 \mathrm{~d}$ (Fig. 3). With such short durations, it is evident from the curve in Fig. 1 that sex ratios must be highly skewed toward females. After calculating the sex ratio for each incubation duration from this curve, and taking the nesting distribution into account, the overall sex ratio, based on 227 recordings of incubation durations over the $6 \mathrm{yr}$, is $89.2 \%$ female.

A
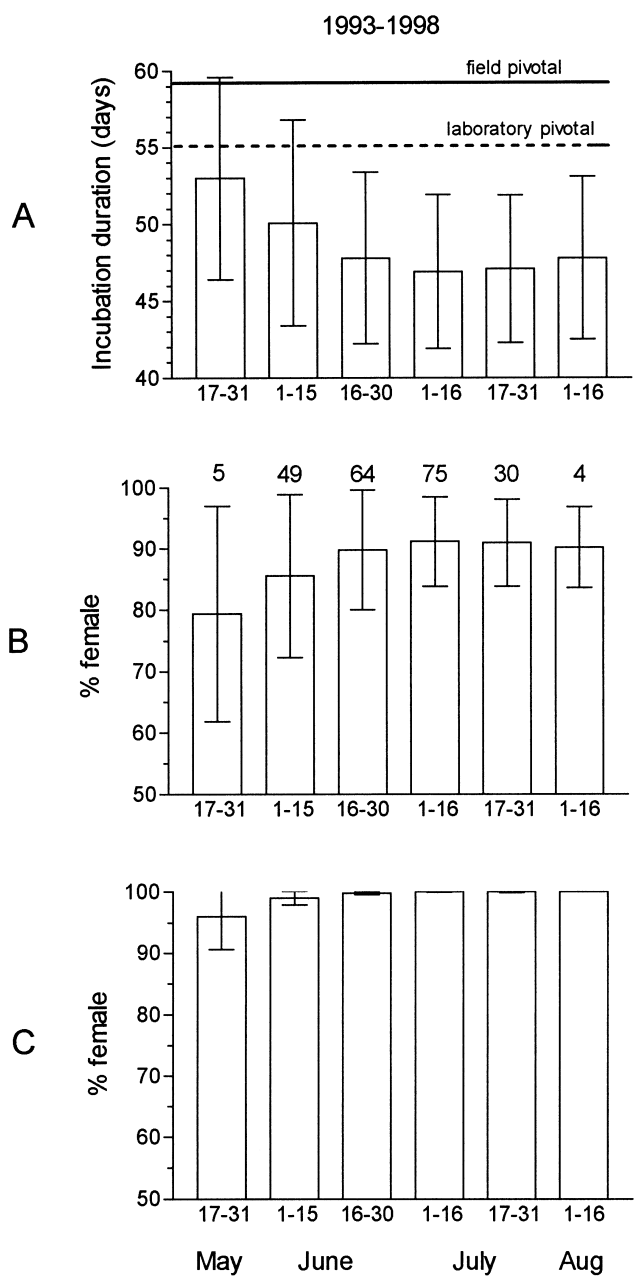

Fig. 3. Caretta caretta. (A) Incubation durations (mean \pm 2 SD) for combined data set for $6 \mathrm{yr}$ at Alagadi, Northern Cyprus. Dashed horizontal line: pivotal incubation duration obtained in laboratory incubation of Brazilian loggerhead turtle eggs; continuous horizontal line: derived field pivotal incubation duration for Brazilian loggerhead turtles (see Fig. 2). (B) Sex ratios (mean $\pm 2 \mathrm{SD}$ ) for the combined data set for the $6 \mathrm{yr}$, as estimated using the curve in Fig. 1 for USA loggerhead turtles; numbers above each bar: sample sizes for each halfmonth bin. (C) Sex ratios (mean \pm 2 SD) for the 6 yr combined, estimated using the derived curve for Brazilian loggerhead turtles in Fig. 2 and the 4.1 hatch-emergence interval; sample sizes as in (A) and (B) 
Table 1. Caretta caretta. Incubation periods of in situ nests recorded at Alagadi and elsewhere in the Mediterranean

\begin{tabular}{|c|c|c|c|c|c|c|}
\hline Beach & Year & Mean & $\mathrm{SE}$ & (n) & $\begin{array}{l}\text { Total nests in } \\
\text { season of study }\end{array}$ & Source \\
\hline \multicolumn{7}{|l|}{ Cyprus } \\
\hline Alagadi & 1993 & 47.9 & 0.6 & $(17)$ & 41 & This study \\
\hline Alagadi & 1994 & 47.9 & 0.4 & $(58)$ & 95 & This study \\
\hline Alagadi & 1995 & 47.7 & 0.5 & (39) & 95 & This study \\
\hline Alagadi & 1996 & 48.1 & 0.5 & $(45)$ & 60 & This study \\
\hline Alagadi & 1997 & 47.8 & 0.5 & $(41)$ & 57 & This study \\
\hline Alagadi & 1998 & 48.7 & 0.7 & $(27)$ & 38 & This study \\
\hline \multicolumn{7}{|l|}{ Greece } \\
\hline Kiparissia & 1987 & 55.5 & 0.9 & $(50)$ & 598 & Margaritoulis (1989) \\
\hline Zakynthos & 1980 & 50.7 & - & (3) & - & Margaritoulis (1985) \\
\hline Zakynthos & 1983 & 57.5 & 2.8 & (6) & 2460 & Sutherland (1985) \\
\hline Crete & 1998 & 49.4 & - & $(30)$ & 345 & Ireland (1998) \\
\hline \multicolumn{7}{|l|}{ Turkey } \\
\hline Dalyan & 1989 & 59.3 & 0.6 & $(47)$ & 235 & Erk'akan (1993) \\
\hline Fethiye & 1993 & 56.9 & 1.0 & $(67)$ & 118 & Turkozan \& Baran (1996) \\
\hline Fethiye & 1994 & 55.0 & - & $(75)$ & 158 & Baran \& Turkozan (1996) \\
\hline Göksu & 1992 & 57.0 & 1.2 & $(25)$ & 89 & van Pigglen (1993) \\
\hline Göksu & 1991 & 54.8 & 1.2 & (33) & 117 & Peters \& Verhoeven (1992) \\
\hline Kizilot & 1990 & 59.6 & - & $(70)$ & 143 & Kaska (1993) \\
\hline Patara & 1992 & 60.0 & - & $(25)$ & 52 & Kaska (1993) \\
\hline
\end{tabular}

\section{Sex ratios calculated using Method 2, based on laboratory data and derived curve for Brazil}

Incubation durations were considerably shorter than the derived field pivotal duration of $59.2 \mathrm{~d}$ obtained for loggerhead turtles nesting in Brazil (Fig. 3). In fact the

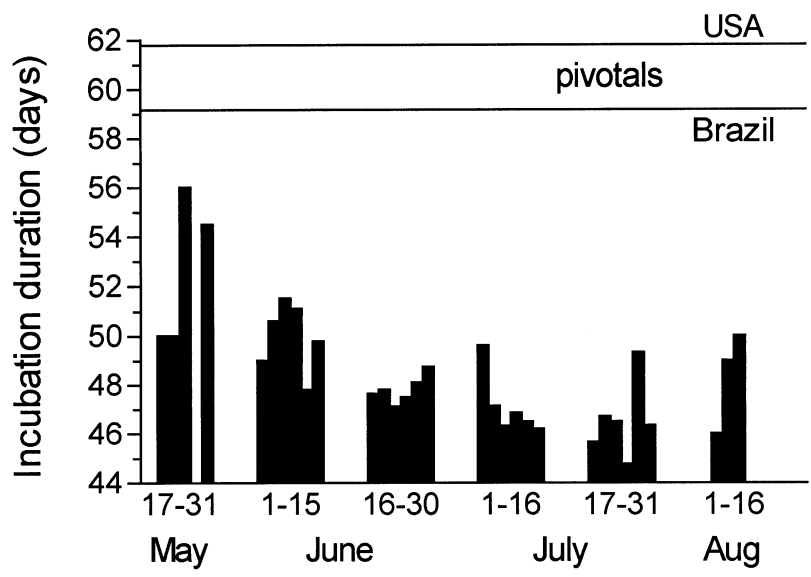

Fig. 4. Caretta caretta. Incubation durations for each year. Data are shown in groups of 6 bars, representing from left to right the years 1993 to 1998 for each time bin. However, sample sizes for May and August bins are 0 to 2 ; therefore, any differences at these times are unreliable. The figure illustrates the similarity in incubation durations between the $6 \mathrm{yr}$ for the main nesting season (June and July) and the shortness of these durations compared to the field pivotal duration for the USA (Fig. 1) and the derived field pivotal incubation duration for Brazil (Fig. 2) durations were even less on average than $59.2-4.1=$ $55.1 \mathrm{~d}$, the pivotal incubation duration in the laboratory. In other words, even if turtles emerged on the day they hatched (hatch-emergence interval $=0$ ), there would be a skew toward female, because the average incubation durations were shorter than the laboratory pivotal value (Fig. 3). When more reasonable hatchemergence intervals are assumed, the overall sex ratio is highly female-biased: $99.6 \%$ assuming a $4.1 \mathrm{~d}$ hatchemergence interval, and $98.4 \%$ assuming a 2 d hatchemergence interval.

\section{Comparisons among years}

As a result of the similarity in incubation duration among different years (Fig. 4), sex ratios are highly biased toward females in all years.

\section{Seasonal pattern of hatch rate and hatching success}

Were the hatch rate (i.e. the proportion of nests which hatched) or hatching success (i.e. the mean proportion of eggs hatched per nest) to vary much across the nesting season, then the sex ratios for turtles hatched might differ from those calculated on the basis of clutches laid. However, a comparable proportion of clutches hatched from each time bin (Fig. 5), and there was no obvious seasonal pattern in hatching success in any year. 


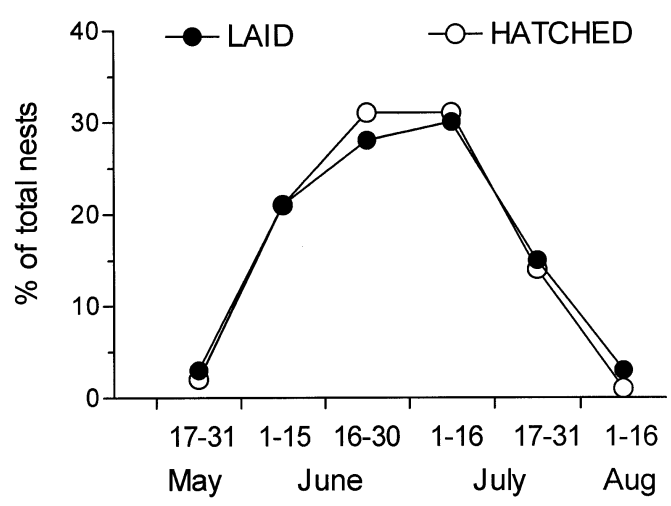

Fig. 5. Caretta caretta. Temporal distributions of clutches laid and hatched. Data are means of percentages for half-month bins for each season. Curves are also closely similar for individual years (data not shown)

\section{DISCUSSION}

Because incubation durations for Caretta caretta were so short, both methods of converting duration to sex ratios gave high skews toward female. It is interesting, especially in cases where the incubation duration is generally close to the pivotal value, to consider which method is superior. The pivotal value (that giving $50 \%$ of each sex) is not the only important aspect of the relationship between incubation duration and sex ratio. The extent of the transitional range of temperatures between $100 \%$ female and $100 \%$ male, where a mixed sex ratio is likely to be produced, is also important. If the curves are not steep, then even though temperatures (and associated incubation durations) are well on the female side of the pivotal value, they may nevertheless still not only produce females (for further discussion of transitional ranges of temperature see Mrosovsky 1994 and Chevalier et al. 1999).

The curve for loggerhead turtles in the USA (Fig. 1) may be too flat: few data points for long incubation durations contribute to this curve, and if such durations produced all males, the curve would become steeper. On the other hand, the curve for loggerhead turtles in Brazil (Fig. 2) may be too steep. It is based on only 2 clutches of eggs. If there is variability in pivotal durations between different clutches, even if the shape of the curves is similarly steep for all individual clutches, an average of several clutches would produce a flatter curve.

On this basis, we tentatively suggest that the true value for Alagadi may lie somewhere between the 89 and $99 \%$ female estimates provided by the 2 methods. In either case, the ratios are highly skewed toward female turtles. This fits with data we have on nest tem- peratures at Alagadi. Temperatures recorded within nests by data-loggers (Orion Components, Chichester, UK) indicate that clutches rarely incubate at temperatures $<29^{\circ} \mathrm{C}$. Mean temperature throughout the incubation ranged from 29.5 to $33.2^{\circ} \mathrm{C}$ (mean $=31.6^{\circ} \mathrm{C}$, $\mathrm{SE}=0.2, \mathrm{n}=23$ nests; Broderick 1997, Broderick \& Godley unpubl. data), with the mean temperature experienced during the middle third of incubation by these same nests ranging from 29.3 to $33.7^{\circ} \mathrm{C}$ (mean = 31.6, $\mathrm{SE}=0.3, \mathrm{n}=23$ ).

Despite the extreme skews toward females, there is no indication that there are insufficient males for fertilisation at Alagadi. Mean annual hatching success of nests which were followed to completion (i.e. excluding those lost to predation or innundation by waves) ranged from 75 to $83 \%$ (Broderick \& Godley 1996). Assuming that similar sex ratios have been produced over a generation time or more, either the few males produced on Alagadi are sufficient to ensure fertilisation, or males originating elsewhere assume this role.

Comparisons between mitochondrial and nuclear DNA in another marine turtle species, the green turtle Chelonia mydas (Karl et al. 1992, FitzSimmons et al. 1997), are consistent with the idea that, although males show some degree of fidelity to courtship grounds in their natal area, they may move among sites more than females (or intercept females in overlapping feeding grounds or en route to breeding grounds). A similar study on loggerhead turtles in Turkey and Cyprus suggested a low level of male-mediated gene-flow (Schroth et al. 1996). However, from what information we have been able to collate, there does not appear to be any large known rookery in the Mediterranean that is likely to produce mostly males, as judged by incubation durations (Table 1). In addition, on beaches other than Alagadi in Northern Cyprus, the mean incubation duration of 70 nests in 1998 was 48.8 d ( $\mathrm{SE}=0.6$; Broderick \& Godley unpubl. data). This is similar to the values for Alagadi (Fig. 3), suggesting a similar, female-biased sex ratio.

In other parts of the Mediterranean, incubation durations are mostly reported to be shorter than $59 \mathrm{~d}$ (Table 1). In addition, in Israel and Egypt, where all nests have been relocated to hatcheries which attempt to mimic natural nest conditions, short incubation durations have been recorded (Israel: mean $=52.7 \mathrm{~d}$, $\mathrm{SE}=0.4, \mathrm{n}=175, \mathrm{Z}$. Kuller pers. comm.; Egypt: mean = 49.3, $\mathrm{SE}=1.1, \mathrm{n}=11, \mathrm{M}$. Clarke pers. comm.). Regrettably, for the largest known loggerhead turtle nesting site in the Mediterranean, Zakynthos, with about 1000 to 2000 nests $\mathrm{yr}^{-1}$, there are very few data available, even though this beach has been extensively monitored for over a decade. However, the mean incubation duration for Kiparissia, which is very close to Zakyn- 
thos $(<100 \mathrm{~km})$, is $<56 \mathrm{~d}$, suggesting a female-biased hatchling production in this region of Greece (cf. Table 1, Fig. 3). It is possible that there is a large aggregation of loggerhead turtles nesting in Libya (Laurent et al. 1997, 1998). We presume that the sand at such a southern location would not be appreciably cooler than elsewhere in the Mediterranean.

Whatever the situation with respect to movement of males, there are implications for sea turtle conservation. If there is a sizeable genetic interchange between male- and female-producing beaches, producing relatively balanced sex ratios overall, then a macro-ecological perspective must be taken to preserve the appropriate sex ratios in the population as a whole (Baptistotte et al. 1999). But if, as seems more likely, the sex ratio is highly female-biased on a number of beaches in the Mediterranean, it would seem wise to pay particular attention to protection of the few male-producing clutches laid at the start of the seasons (Mrosovsky et al. 1984).

The proximate and ultimate causes for highly female-biased sex ratios in loggerhead turtles remain unknown. The more often such ratios are found, the less likely it is for sampling error to be the explanation. The present analysis adds the Mediterranean to the USA and Brazil as places where loggerhead turtles are producing some highly skewed hatchling sex ratios. Why frequency-dependent pressures (Fisher 1930) have not led to more balanced sex ratios in loggerhead turtles remains puzzling.

Acknowledgements. We thank Peggy Salmon for help, and the Natural Sciences and Engineering Council of Canada for support. Many volunteers offered important contributions to the field work. Organisations that funded the Glasgow University Turtle Conservation Expeditions 1993-1998 were: British Association of Tortoise Keepers, British Chelonia Group, British Ecological Society, Carnegie Trust, Cross Trust, European Commission (DG1B/1A), Institute of Biology, Glasgow Natural History Society, Glasgow University Court, MEDASSET UK, People's Trust for Endangered Species, North of England Zoological Society, Zebra Foundation. The Department of Environmental Protection and the Society for the Protection of Turtles gave logistic support in Northern Cyprus. Zeev Kuller, Mike Clarke and Sally Hopkins-Murphy kindly provided unpublished data. We thank Matthew Godfrey for comments.

\section{LITERATURE CITED}

Baptistotte C, Scalfoni JT, Mrosovsky N (1999) Male producing thermal ecology of a southern loggerhead nesting beach in Brazil: implications for conservation. Anim Conserv (Zool Soc Lond) 2:9-13

Baran I, Turkozan O (1996) Nesting activity of the loggerhead turtle (Caretta caretta) at Fethiye Beach, Turkey in 1994. Chelonian Conserv Biol 2:93-96

Broderick AC (1997) The reproductive ecology of marine tur- tles Chelonia mydas and Caretta caretta nesting at Alagadi, Northern Cyprus, eastern Mediterranean. PhD thesis, University of Glasgow

Broderick AC, Godley BJ (1996) Population and nesting ecology of the green turtle, Chelonia mydas, and the loggerhead turtle, Caretta caretta, in northern Cyprus. Zool Middle East 13:27-46

Broderick AC, Godley BJ (2000) Temperature and the temporal spread of marine turtle nesting and hatching in Cyprus, Eastern Mediterranean. In: Abreu-Grobois FA, Briseño-Dueñas R, Marquez R, Sarti L (eds) Proceedings of the 18th Annual Symposium on Sea Turtle Biology Conservation, US Department of Commerce, Washington, p 181-183, NOAA Tech Memo NMFS-SEFSC-436

Chevalier J, Godfrey MH, Girondot M (1999) Significant difference of temperature-dependent sex determination between French Guiana (Atlantic) and Playe Grande (Costa Rica, Pacific) leatherbacks (Dermochelys coriacea). Ann Sci Nat Zool Biol Anim 20:147-152

Encalada SE, Bjorndal KA, Bolten AB, Zurita JC, Schroeder B, Possardt E, Sears CJ, Bowen BW (1998) Population structure of loggerhead turtle (Caretta caretta) nesting colonies in the Atlantic and Mediterranean as inferred from mitochondrial DNA control region sequences. Mar Biol 130: $567-575$

Erk'akan F (1993) Nesting biology of loggerhead turtles Caretta caretta on Daylan beach, Mugala, Turkey. Biol Conserv 66:1-4

Fisher RA (1930) The genetical theory of natural selection. Clarendon Press, Oxford

FitzSimmons NN, Moritz C, Limpus CJ, Pope L, Prince R (1997) Geographic structure of mitochondrial and nuclear gene polymorphisms in Australian green turtle populations and male biased gene flow. Genetics 147: 1843-1854

Glen F, Godley BJ, Broderick AC, Furness RW (2000) Patterns of emergence of hatchling loggerhead and green turtles in Northern Cyprus. In: Abreu-Grobois FA, Briseño-Dueñas R, Marquez R, Sarti L (eds) Proceedings of the 18th Annual Symposium on Sea Turtle Biology Conservation, US Department of Commerce, Washington, p 224-227, NOAA Tech Memo NMFS-SEFSC-436

Godfrey MH, Mrosovsky N (1997) Estimating the time between hatching of sea turtles and their emergence from the nest. Chelonian Conserv Biol 2:581-585

Godfrey MH, D'Amato AF, Marcovaldi MA, Mrosovsky N (1999) Pivotal temperatures and predicted sex ratios for hatchling hawksbill turtles from Brazil. Can J Zool 77: 1465-1473

Hanson J, Wibbels T, Martin RE (1998) Predicted female bias in hatchling sex ratios of loggerhead sea turtles from a Florida nesting beach. Can J Zool 76:1850-1861

Ireland J (1998) Aspects of the nesting biology in the loggerhead sea turtle Caretta caretta (Linneaus, 1758) and a comparison of the nesting success rates of hatchlings between in situ and relocated nests at Reythymno, North Crete, Greece. Undergraduate dissertation, School of Ocean Science, Menai Bridge, Anglesey

Karl SA, Bowen BW, Avise JC (1992) Global population genetics structure and male mediated gene flow in the green turtle (Chelonia mydas): RFLP analyses and anonymous nuclear loci. Genetics 131:163-175

Kaska Y (1993) Investigation of the Caretta caretta population in Patara and Kizilot. MSc thesis, Graduate School of Natural and Applied Sciences, Dokuz Eylul University, Izmir

Kaska Y, Downie R, Tippett R, Furness RW (1998) Natural temperature regimes for loggerhead and green turtle 
nests in the eastern Mediterranean. Can J Zool 76: 723-729

Laurent L, Bradai MN, Hadoud DA, El Gomati HM (1997) Assessment of sea turtle nesting activity in Libya. Mar Turtle Newsl 76:2-6

Laurent L, Casale P, Bradai MN, Godley BJ, Gerosa G, Broderick AC, Schroth W, Schierwater B, Levy AM, Freggi D, Abd El-Mawla NEM, Hadoud DA, Gomati HE, Domingo M, Hadjichristophorou M, Kornaraky L, Demirayak F, Gautier CH (1998) Molecular resolution of marine turtle stock composition in fishery bycatch: a case study in the Mediterranean. Mol Ecol 7:1529-1542

Marcovaldi MA, Godfrey MH, Mrosovsky N (1997) Estimating sex ratios of loggerhead turtles in Brazil from pivotal incubation durations. Can J Zool 75:755-770

Margaritoulis D (1985) Preliminary observations on the breeding behaviour and ecology of Caretta caretta in Zakynthos, Greece. Biol Gallo-Hellenica 10:323-332

Margaritoulis D (1989) Loggerhead sea turtle nesting: Kiparissia Bay, Greece. Mar Turtle Newsl 45:5-6

Mrosovsky N (1994) Sex ratio of sea turtles. J Exp Zool 270: $16-27$

Mrosovsky N, Provancha JA (1992) Sex ratio of hatchling loggerhead sea turtles: data and estimates from a 5-year study. Can J Zool 70:530-538

Mrosovsky N, Hopkins-Murphy SR, Richardson JI (1984)

Editorial responsibility: Otto Kinne (Editor),

Oldendorf/Luhe, Germany
Sex-ratio of sea turtles - seasonal changes. Science 225: 739-741

Mrosovsky N, Baptistotte C, Godfrey MH (1999) Validation of incubation durations as an index of sex ratio of sea turtle hatchlings. Can J Zool 77:831-835

Peters A, Verhoeven KJF (1992) Breeding success of the loggerhead, Caretta caretta, and the green turtle, Chelonia mydas, in the Göksu Delta, Turkey. Department of Animal Ecology, University of Nijmegen (Rep. No. 310)

Provancha JA, Corsello MA (1998) Multi-annual sand temperatures collected at Cape Canaveral, Florida and relationships to Central Florida sea turtle sex ratios. In: Epperly SP, Braun J (eds) Proceedings of the 17th Annual Sea Turtle Symposium. US Department of Commerce, Washington, p 248-249, NOAA Tech Memo NMFSSEFSC-415

Schroth W, Streit B, Schierwater B (1996) Evolutionary handicap for turtles. Nature 384:521-522

Sutherland J (1985) Marine turtles in Greece and their conservation. Mar Turtle Newsl 32:6-8

Turkozan O, Baran, I (1996) Research on the loggerhead turtle, Caretta caretta of Fethiye Beach. Turk J Zool 20: 183-188

van Pigglen DCG (1993) Marine turtle survey in the Goksu delta, Turkey, June-August 1991. Department of Animal Ecology, University of Nijmegen (Rep No. 314)

Submitted: May 26, 2000; Accepted: August 22, 2000 Proofs received from author(s): December 15, 2000 